\title{
Green economy as a basis for designing sustainable development programs for the Russian enterprises
}

\author{
Larisa Yuzvovich*, Ekaterina Polyakova, Larisa Pustovalova, and Oksana Lavrova \\ Ural State University of Economics, st. March 8, 62/45, 620144 Yekaterinburg, Russia
}

\begin{abstract}
At present, a number of economic actions undertaken by the Russian enterprises for development, directly or indirectly, lead to water and air pollution, nuclear radiation and many other perverse outcomes. The environment destruction is closely related to the enterprises activities that implement minerals and natural resources in their performance. If an enterprise establishes a reliable organizational management process, analyses the research and production process and implements modern equipment, then it can, to a certain extent, avoid environmental pollution, thereby preserving space for the economic activity.
\end{abstract}

\section{Introduction}

The importance of an environmental economics increase is determined by the environmental crises escalation and the urgency of building the environmental sustainability. Ecological economics is both a transdisciplinary and interdisciplinary field of the scientific research devoted to the interdependence and co-evolution of the economy and natural ecosystems of a person in terms of time and space. Taking into consideration the fact, that many cities account for $70-80 \%$ of global economic activity related to the natural resources implementation, the relevance of the topic referring to the environmental economics plays a key role in problem - solving concerning the sustainable economic growth. The importance of this issue was highlighted by William Nordhaus Sterling, a professor of economics at Yale University and a leading global economist on climate change. He has spent most of his four decades trying to convince the government to tackle climate change, preferably by imposing a carbon tax. His thorough scientific research was highly appreciated by the global ecological community, and in 2018 he was awarded the Nobel Prize in Economics for "Integrating Climate Change into Long-Term Macroeconomic Analysis" [11].

\section{Materials and methods}

In the time of industrialization prosperity, ecology and economics were viewed as opposite issues, and this misconception was widely spread. People are more concerned with

\footnotetext{
* Corresponding author:cabelkova@pef.czu.cz
} 
economic development than improving or reducing negative environmental impacts. This statement is confirmed by Figure 1, which reflects the attitude of people to the environmental problems in Russia over the past 20 years.

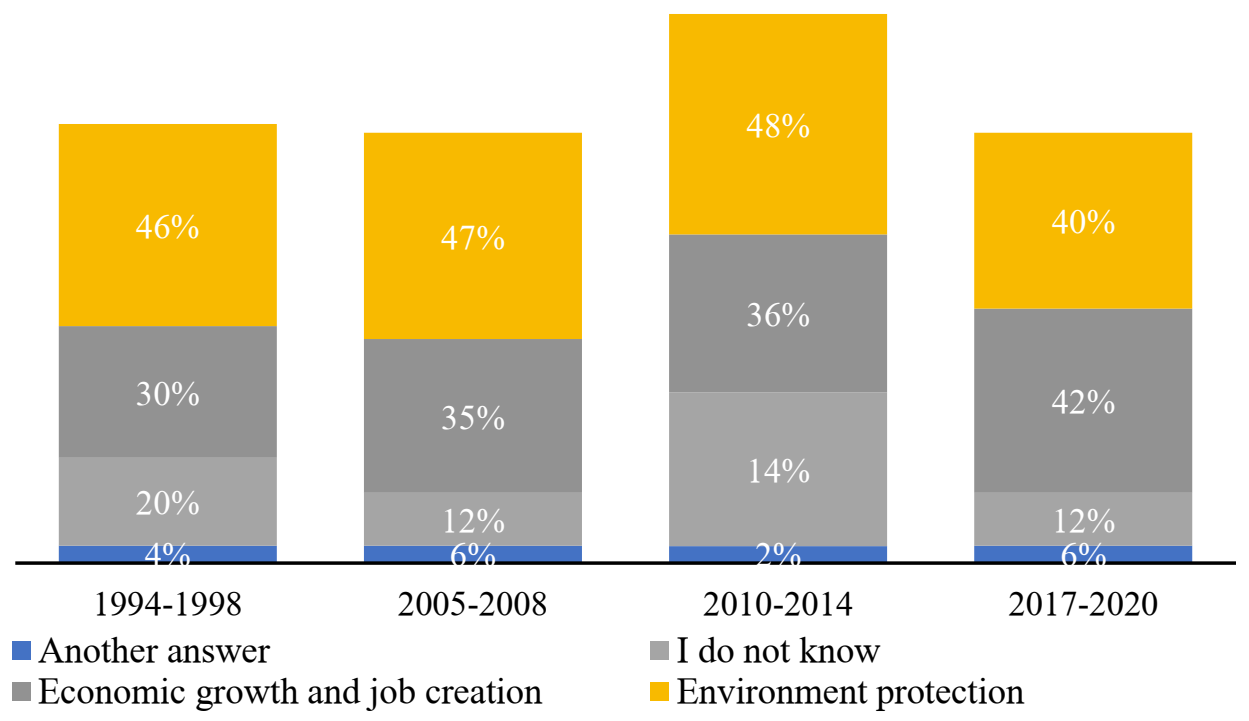

Fig. 1. Changing of people' attitude towards the environmental problems in Russia

Today it is widely recognized that environmental problems are closely connected with the economy, this is why it is impossible to develop a modern economy without solving the environmental problems. An indisputable evidence of the relationship between economic and natural processes is presented in Table 1.

Table 1. Economic processes, exerting a significant influence on natural objects

\begin{tabular}{|l|l|}
\hline $\begin{array}{c}\text { Consequences of the enterprises' } \\
\text { performance that do not comply with } \\
\text { "The environment protection" law }\end{array}$ & \multicolumn{1}{|c|}{ Economic problems } \\
\hline $\begin{array}{l}\text { Environmental pollution with industrial } \\
\text { and household waste }\end{array}$ & $\begin{array}{l}\text { Rising costs for storage, destruction, waste utilization } \\
\text { and pollution liquidation }\end{array}$ \\
\hline $\begin{array}{l}\text { Agricultural land reduction, soil fertility } \\
\text { decrease }\end{array}$ & $\begin{array}{l}\text { Food supply aggravation for the population, an increase } \\
\text { in the cost of recultivation and remediation of lands }\end{array}$ \\
\hline $\begin{array}{l}\text { Depletion of natural resources, } \\
\text { deterioration of their geological position }\end{array}$ & $\begin{array}{l}\text { Cost increase for raw materials on the world market, } \\
\text { declining production efficiency, increasing costs for } \\
\text { non-renewal exploitation }\end{array}$ \\
\hline
\end{tabular}

Land is the main source of materials and resources, and once these resources are exhausted, a financial crisis can be observed in the countries directly dependent on the natural resources extraction. Gaylord Nelson, a US Senator in the 1960s, acknowledged that: "The economy is a daughter company which is entirely dependent on the environment." Rowan Williams, in his article "Ecology and economics go side by side", reported that: "Economics and ecology cannot be separated. The environmental consequences of economic development are in no way an "external effect" as it is expressed in the economic jargon; it is a positive depletion of real wealth, human and 
natural capital. Striving for an economy without ecology means to try to manage the environment without knowing its essence and not caring how it works by itself, aiming at formulating human laws, abstracted from or ignored by the laws of nature".

Actually, the economic activities of the enterprises have an unchallenged damage to the environment. The data on air pollution indicators caused by the enterprises are presented in Figure 2.

The diagram shows that the Russian enterprises are trying to reduce the emission of substances that pollute the atmosphere, but at the same time they are not in a hurry to increase the share of the utilized harmful substances.

Nature provides many free services such as food, shelter, clean air, water and protection from harmful sun rays. It contains all the resources necessary for life to go on as usual. The complex functions of ecological systems in forests and oceans not only provide humanity with all vital ingredients, but also contribute to influencing the climate, storing water resources, preventing soil erosion, and have an impact on the sustainable development of the ecological systems in many countries.

The natural environment is a necessary material prerequisite for the development of the enterprises. It contains many components such as subsoil, trees, coal, oil and many others. Most of these components are essential for the uninterrupted production and businesses operation. In case of the natural environment destruction, enterprises may face the problem connected with means of production shortage at the micro level. At the macro level, businesses may lose space for their economic activity. Ultimately, the economic development of the enterprises will get under blow inevitably. This is why enterprises that play an important role in the economic country's development must fulfill their social responsibility in terms of the environmental protection.
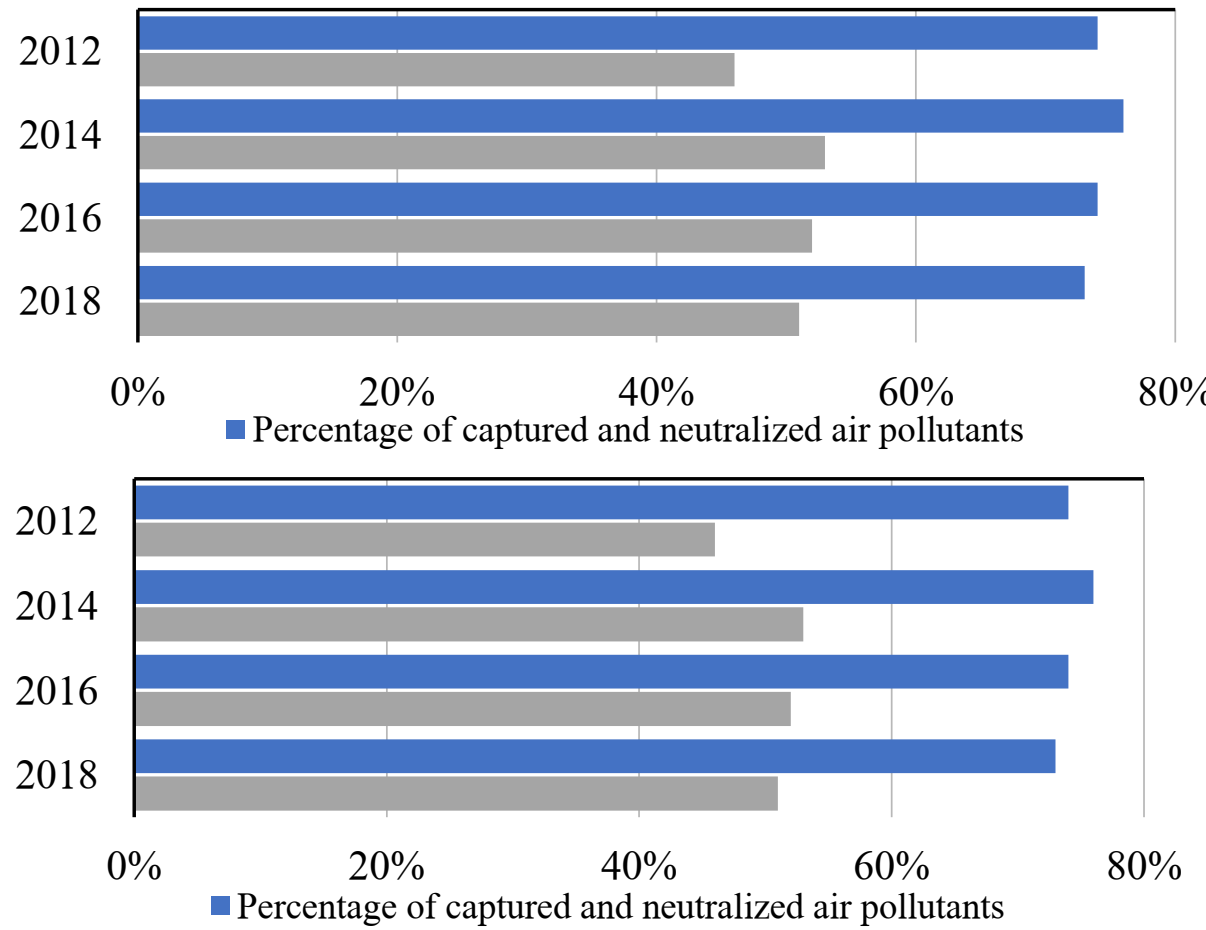

Fig. 2. Dynamics of leveling air pollution indicators by the enterprises

Most of the Russian enterprises usually accept a traditional extensive economic model that reduces investment in the environmental protection equipment due to the simplified 
production management and poor environmental awareness. Consequently, this model can provide enterprises with a significant economic benefit within a short time. However, in the long term, social status, reputation, sustainable innovation and enterprise development will be affected by the environmental damage.

\section{Empirical model}

Applying to the examples of the environmental protection and economic development, it becomes evident that the state plays a significant role in the development of the ecological economy.

The Government of the Russian Federation is actively investigating the causes of environmental destruction, undertaking certain measures to minimize them. In 2014, the state program "Environmental Protection" was approved, where the main goal is to increase the level of the environmental safety and to preserve natural systems [7]. The Federal Law "On Environmental Protection", which regulates the relations between a society and a nature in the field of economic activities affecting the natural environment, plays a significant positive role [1].

The law defines human rights in terms of a favorable environment, and also delegates responsibilities of every citizen to preserve nature and natural resources, which are considered as an integral part of the environment. It also determines a list of environmental objects, including soils, near-space and the ozone layer. The Federal law obliges all facilities, regardless of their ownership form, to assess their future environmental impact at the design and planning stage. At present, the Russian state continues to finance measures to protect Lake Baikal, approves the rules for granting subsidies to regions for purchasing garbage containers, and also approves a plan of implementing the second stage of the Strategy for activities in the field of hydrometeorology and related areas until 2030.

\section{Results and discussions}

Semyon Gordyshevsky, a Chairman of the Board of the Ecological Union, highlighted the importance of introducing environmental protection measures at the Russian enterprises at the interregional online marathon "Ecology of Russia. Regional aspect": "The flagships of the modern economy should have an economic code under which the enterprise's policy will be aimed at reducing the negative impact on the environment "[9].

For a clearer understanding of the importance of measures to prevent environmental impact, it is worth considering a subsidiary of the largest Russian transnational energy company OOO "Gazprom transgaz Yugorsk".

OOO "Gazprom transgaz Yugorsk" is the largest gas transmission company of PAO Gazprom, engaged in transporting gas from the North of Western Siberia oil fields (Medvezhye, Urengoyskoye, Yamburgskoye, Zapolyarny and others) to consumers in the European part of the country, CIS countries and outside the Commonwealth of Independent States [8]. In order to conservate natural objects and reduce the adverse environmental impact indicators, the Company assumes the following obligations:

1. Reduce the adverse environmental impact.

2. Ensure resource saving of production processes at all the stages.

3. Find a balanced and socially acceptable combination between economic growth and a favorable environment conservation.

Then, it is worth considering the application result of the environmental policy at the enterprise, presented in table 2 . 
Table 2. Analysis and results of the goals set by OOO "Gazprom transgaz Yugorsk" in the field of environmental policy for 2017-2019.

\begin{tabular}{|c|c|c|c|c|c|}
\hline \multirow{2}{*}{ Corporate environmental goal } & \multicolumn{3}{|c|}{ Indicators } & \multicolumn{2}{c|}{$\begin{array}{c}\text { The degree of goal } \\
\text { achievement, } \%\end{array}$} \\
\cline { 2 - 6 } & 2017 & 2018 & 2019 & $2018 / 2017$ & $2019 / 2018$ \\
\hline $\begin{array}{c}\text { Methane emissions into the } \\
\text { atmosphere, } \%\end{array}$ & 50 & 54,2 & 36,6 & $(4,2)$ & 17,6 \\
\hline $\begin{array}{c}\text { Emissions rate of nitrogen oxides } \\
\text { into the atmosphere, } \mathrm{t} / \mathrm{m} \text { m.m3 }\end{array}$ & 5,14 & 5,13 & 5,04 & 0,01 & 0,09 \\
\hline $\begin{array}{c}\text { Effluent discharge into surface } \\
\text { water bodies, \% }\end{array}$ & 23,6 & 11,9 & 8,3 & 11,7 & 3,6 \\
\hline $\begin{array}{c}\text { Excessive exposure fees, thousand } \\
\text { rubles }\end{array}$ & 135 & 48 & 1 & 87 & 47 \\
\hline
\end{tabular}

The dynamics of the target environmental indicator "methane emissions into the atmosphere" shows a decrease in 2019, determined by the implementation of the following measures:

1. Partial gas bypassing from the repaired sections of the gas pipeline

2. Gas pumping using a gas compressor unit for own needs in adjacent sections of gas pipelines.

3. Gas pumping from sections of the hydraulic structures for own technological needs.

Compared to 2017 , the indicator has increased by $4.2 \%$, but compared to 2018 , it has decreased by $17.6 \%$.

The indicator "emissions rate of nitrogen oxides into the atmosphere" decreases in 2018 by $0.01 \mathrm{t} / \mathrm{mln} . \mathrm{m} 3$, in 2019 - by $0.09 \mathrm{t} / \mathrm{mln} . \mathrm{m} 3$ due to the implementation of the following measures:

1. Optimization of the compressor department operating mode based on the implementation of the modeling complexes.

2. Installation of PST-type combustion chambers at RFT-10-4, RFT-25IR.

The indicator "effluent discharge into surface water bodies" decreases in 2018 by $11.7 \%$, in 2019 - by $3.6 \%$.

The indicator decrease is determined by the implementation of measures for the discharged water purification:

1. Repair of the direct and indirect equipment of the sewerage station.

2. Preventive works, focused on reliable and efficient operation of cleansing structures, as well as optimization of approaches to the regulation and set of standards for the pollutant discharged limits into the surface water bodies.

The dynamics of the target environmental indicator "excessive exposure fees" demonstrates a decrease in 2018 by 87 thousand rubles, in 2019 - by 47 thousand rubles. This decrease is associated with a number of the following activities:

1. Quota plan implementation.

2. Monitoring compliance with the standards of permissible discharges, emissions, and waste disposal.

3. Prevention of exceeding the established standards. 


\section{Conclusions}

Thus, the goals set for the enterprise have been met, and the ecological effect from the environmental protection programs implementation demonstrates:

1. Reducing the adverse environmental impact.

2. Reducing the risk of emergencies associated with the adverse environmental impact.

3. Compliance with the legal requirements and accepted obligations.

4. Efficiency improvement of the environmental management system.

5. Natural resources saving.

Expressing a general assessment, we can say that ecological economics is a relatively new phenomenon for the Russian reality. However, it is worth paying more attention to this area, since it covers issues related to the problems of regulating the relationship between a person and a nature based on economic mechanisms that contribute to resource saving, reduction of the environmental pollution, as well as the protection of the biological diversity of our country.

\section{References}

1. The Federal Law "On Environmental Protection" dated 10.01.2002 (adopted by the State Duma of the Federal Assembly of the Russian Federation, 20.12.2001, as amended).

2. V.V. Bogatyreva, Alternative fuel and energy resources: economic and managerial aspects of use in the context of innovative development of society: a manual, 323 (2017)

3. V. A. Vasilenko, Ecology and economics: problems and searches for ways of sustainable development, 346 (2004)

4. K.V. Papenov, Environmental Economics, 900 (2006)

5. Modern trends in environmentally sustainable development. International scientific conference dedicated to the memory of an academician T.S. Khachaturov, Ed. S. N. Bobyleva, I. Yu. Khovavko, 202 (2018)

6. S. N. Bobylev, World of new economy, 3, 90 (2017)

7. Official website of the Government of Russia, http://government.ru.

8. The official website of Gazprom transgaz Yugorsk, https://yugorsk-tr.gazprom.ru.

9. Official site Komersant, https://www.kommersant.ru.

10. Official site of RBC, https://trends.rbc.ru.

11. Official site of the Nobel Prize, https://www.nobelprize.org. 